\title{
Attitudes and interaction practices towards distance education during the pandemic
}

\author{
Çağdaş Ümit Yazgan ${ }^{1}$ (1)
}

Received: 9 April 2021 / Accepted: 30 November 2021 / Published online: 21 January 2022

(C) The Author(s), under exclusive licence to Springer Science+Business Media, LLC, part of Springer Nature 2021

\begin{abstract}
The COVID-19 pandemic has affected educational institutions deeply and globally. In the course of the pandemic, countries around the world have tried to fill the gap that has arisen in traditional face-to-face education with emergency web-based distance education systems. This study aims to evaluate the possibilities and limitations of emergency distance education conducted during the pandemic period, based on university students' approach-avoidance attitudes towards distance education and their distance education experiences. This study, using a mixed method, was designed with explanatory sequential design. The research was conducted at a state university in Turkey. Quantitative data were collected through an online questionnaire $(n=684)$, and qualitative data were collected from 14 student participants through semi-structured online interviews. In the quantitative dimension, it was determined that students' avoidance attitudes towards distance education were stronger than their approach attitudes, and there were significant differences between student attitudes and various variables. In the qualitative dimension, it has been revealed that the interactions between both student-student and student-lecturer weakened with distance education during the pandemic period, but these interactions gained some new qualities. It was concluded that the interest towards the lessons conducted only through lecture notes weakened, the contents became functional at the point of clarifying the boundaries of the lessons, and increased the education load at the point of concentration. It was revealed that distance education in home conditions includes both opportunities and limitations in terms of interactions.
\end{abstract}

Keywords Distance education - COVID-19 - Emergency distance education · Interactions $\cdot$ Attitudes $\cdot$ Sociology of education

Çă̆daş Ümit Yazgan

cumityazgan@nevsehir.edu.tr

1 Department of Sociology, Nevşehir Hacı Bektaş Veli University, 2000 Evler Neighborhood, Zübeyde Hanım Street, 50300 Nevşehir, Turkey 


\section{Introduction}

The COVID-19 pandemic caused significant changes in the functioning of basic social institutions such as economy, politics, family, education, and the daily lives of individuals in a short period of time. The pandemic especially impacted educational institutions. Approximately $92 \%$ of the world student population was affected by this process. Face-to-face training was interrupted in 192 countries. About 1.6 billion students in the world (International Labor Organization, , 2020) were affected by the closure of schools due to the pandemic. In order to reduce the impact of the pandemic on education and control the spread of COVID-19, many countries have turned to distance education (Chen et al., 2020). As an alternative in this process, it is possible to say that Web-based distance education systems offer important opportunities for educational institutions and students by trying to fill the gap in traditional-face-to-face education (Vlachopoulos, 2020) and assume a 'savior' function.

The changes brought about by the pandemic in the education system in Turkey are in parallel with the rest of the world. A total of 24,901,925 students, 7,198,987 of these at the higher education level, were affected by the closure of schools (United Nations Educational, Scientific and Cultural Organization, 2020). In Turkey, an attempt has been made to mitigate the negative effects of the pandemic in higher education by the management and organization of distance education, supporting digital tools and technical infrastructure, increasing the adaptation of the instructor to the process and creating various teaching materials (Karadağ \& Yücel, 2020). In this process, various means can be used to evaluate this rapid change in higher education in Turkey.

Undoubtedly, investigation of students' attitudes towards, and interaction experiences of, distance education during the pandemic will be decisive in evaluating the distance education process. This study examines the possibilities and limitations of the emergency distance education carried out in Turkey during the pandemic, based on the attitudes and interaction practices of university students towards distance education.

\section{Literature review}

The "emergency" nature of distance education, which has become widespread due to the COVID-19 pandemic, stands out. Normally, distance education is a multidisciplinary field that develops over time and meets the diverse needs of students. However, emergency distance education includes a temporary solution to an emergency problem (Bozkurt \& Sharma, 2020) and introduces temporary changes that can be an alternative to the current education system. The aim of emergency distance education is to create a temporary educational support that will be established quickly and reliable access will be provided, rather than creating a permanent and robust education ecosystem (Hodges et al., 2020). Although distance education and emergency distance education are very closely related concepts, it is not possible to evaluate these concepts in the same terms (Bozkurt \& Sharma, 2020). 
There are many studies in the literature regarding emergency distance education conducted during the pandemic. In the studies conducted in the pandemic, it is stated that emergency distance education has benefits such as reducing training costs (Saleh et al., 2021), offering flexible use of time (Yates et al., 2020), overcoming the limitations of space (Fatonia et al., 2020), learning new technologies (Aguilera-Hermida, 2020), being able to control the pace of learning (Irembere \& Lubani, 2020), ease of accessibility to lecturers (Aduba \& Mayowa-Adebara, 2020), being able to watch the lessons again (Mishra et al., 2020), educational opportunity in a comfortable environment (Fatonia et al., 2020), and devoting more time to family members (Aguilera-Hermida, 2020). Along with the opportunities identified in these studies, during the pandemic, it is stated that there are limitations such as a decrease in social interaction related to emergency distance education (Dutta \& Smita, 2020) and working with peer groups (Yates et al., 2020), becoming difficult to interact with lecturers (Fatonia et al., 2020), delays in feedback (Irembere \& Lubani, 2020), concentration of content (Aduba \& Mayowa-Adebara, 2020), increasing educational load of students (Coman et al., 2020), weakening of learning in the home environment (Yates et al., 2020), and technical problems (Dutta \& Smita, 2020). When the studies are evaluated as a whole, it is possible to compare the emergency distance education during the pandemic to a maze that includes both various possibilities and various limitations.

Student attitudes towards distance education can provide information about the quality of the use of distance education (Liaw et al., 2007). Interaction practices, like attitudes, are one of the most important indicators for the quality of online learning (Han \& Johnson, 2012). Interaction plays an important role in promoting student success and satisfaction. One of the main reasons for the dominant problems such as drop-out or failure in the distance education process is the lack of interaction (Purarjomandlangrudi \& Chen, 2020). Interaction can fill up the physical and psychological gap that arises in the distance learning process (Van Den Berg, 2020) by playing an integrative role for elements, such as teacher, student, and content (Bernard et al., 2009). Interactive applications in distance education improve students' current knowledge and positive learning habits, and increase the influence of instructors in classroom management (Zhang \& Yu, 2021).

This study aims to evaluate the possibilities and limitations of emergency distance education conducted in Turkey during the pandemic period, based on university students' approach-avoidance attitudes towards distance education and their distance education experiences. The study used a mixed method. Accordingly, students' approach-avoidance attitudes were analyzed with a quantitative approach, while their interaction practices were examined with a qualitative approach. The multi-dimensional study of distance education during the pandemic, and the holistic nature of the method used, add an original value to the research.

In the quantitative dimension of the research, the following question was investigated:

1. At which level are the students' approach and avoidance attitudes towards distance education during the pandemic? 
In the qualitative dimension of the research, the following question was investigated:

2. How are the interaction practices of students towards distance education, in terms of approach andavoidance, during the pandemic?

\section{Method}

\subsection{The type and Design of the Study}

The mixed method, which includes both qualitative and quantitative approaches, was used in this study. Assuming that a single data type would not be enough for the purposes of the study (Creswell \& Plano-Clark, 2015), different dimensions (attitudes and interaction practices) were examined with different approaches (quantitative and qualitative) (Teddlie \& Tashakkori, 2009), and it was aimed to obtain complementary data (Morse, 1991). Quantitative data were used to reveal general trends, and qualitative data were used to undertake an in-depth examination of experiences related to the phenomenon from an inside viewpoint (Creswell, 2015).

In this study, explanatory sequential design was used. The research started with the quantitative phase. In the second stage, a qualitative study was conducted to explain how the quantitative results were formed (Creswell, 2015). The first stage attempted to determine the level of approach and avoidance attitudes of students towards distance education via quantitative investigation. The second stage sought to reach the essence of the experiences that led to approach and avoidance. A survey study (Creswell, 2014) was conducted to determine the level of attitudes in the quantitative dimension, and a phenomenological study (Creswell, 2014) was conducted to reach the essence of interaction experiences in the qualitative dimension.

\subsection{Participants}

This research was carried out in three faculties and a vocational school, which were determined by single-stage cluster sampling among seven faculties and two vocational schools located on the central campus of a state university in Turkey. An e-questionnaire link was sent to all students $(\mathrm{N}=6492)$ studying in the selected clusters. The rate of students who responded to e-questionnaire was $10.53 \%(n=684)$.

The mean age of the students participating in the quantitative component of the study was $21.54 \pm 2.61 ; 82.2 \%$ of them were female, and $17.8 \%$ were male. Also, $28.1 \%$ were first-year and $24.1 \%$ were second-year students. Regarding the place of residence, $15.2 \%$ of the families of the participants were found to live in a village, and $49.4 \%$ in a city. Concerning the income levels, $66.4 \%$ of the participants were from low-income families and $12.3 \%$ from high-income families. Other descriptive data were as follows: $15.5 \%$ of the participants were vocational school students; $44 \%$ were from the Faculty of Arts and Sciences; $33.6 \%$ spent $3-4$ h a day online; $8.6 \%$ spent $7 \mathrm{~h}$ or more on the Internet (Table 1). 
Table 1 Demographic Characteristics of the Participants in the Quantitative Dimension

\begin{tabular}{|c|c|c|}
\hline Variables & $\mathrm{n}$ & $\%$ \\
\hline \multicolumn{3}{|l|}{ Gender } \\
\hline Male & 122 & 17.8 \\
\hline Female & 562 & 82.2 \\
\hline \multicolumn{3}{|l|}{ Grade } \\
\hline 1.Grade & 192 & 28.1 \\
\hline 2.Grade & 165 & 24.1 \\
\hline 3.Grade & 173 & 25.3 \\
\hline 4.Grade & 154 & 22.5 \\
\hline \multicolumn{3}{|l|}{ The family's place of residence } \\
\hline Village & 104 & 15.2 \\
\hline Town & 242 & 35.4 \\
\hline City & 338 & 49.4 \\
\hline \multicolumn{3}{|l|}{ Family average monthly income } \\
\hline Low & 454 & 66.4 \\
\hline Middle & 146 & 21.3 \\
\hline High & 84 & 12.3 \\
\hline \multicolumn{3}{|l|}{ Faculty } \\
\hline Faculty of Science and Literature & 301 & 44 \\
\hline $\begin{array}{l}\text { Faculty of Economics and } \\
\text { Administrative Sciences }\end{array}$ & 169 & 24.7 \\
\hline Faculty of Education & 108 & 15.8 \\
\hline Vocational School & 106 & 15.5 \\
\hline \multicolumn{3}{|l|}{ Daily Internet Usage Time } \\
\hline $1-2 \mathrm{~h}$ & 169 & 26.8 \\
\hline $3-4 \mathrm{~h}$ & 212 & 33.6 \\
\hline $5-6 \mathrm{~h}$ & 196 & 31.1 \\
\hline $7 \mathrm{~h}$ or more & 54 & 8.6 \\
\hline
\end{tabular}

Participants in the qualitative component were included in the study in accordance with three criteria. The criteria for inclusion in the study are volunteering, regular attendance of distance education, and the score obtained from the scale applied at the quantitative stage. Since this research design aims to explain the initial quantitative results, participants in the qualitative stage were selected from among the students who participated in the quantitative data collection stage (Creswell \& PlanoClark, 2015). Among the candidate participants, 7 students with scores close to the average score of avoidance attitude $(\bar{X}=38.66 \pm 9.08)$ and 7 students with scores close to the average score of approach attitude $(\bar{X}=19.67 \pm 8.92)$ were included in the qualitative study. A total of 14 participants took part in the qualitative component of the research. The demographic characteristics of the students participating in the qualitative dimension are presented in Table 2.

The mean age of the participants in the qualitative dimension was $19.85 \pm 1.1$. Female students make up $71.5 \%$ of the participants. In addition, $42.8 \%$ of the 
Table 2 Characteristics of Participants in Qualitative Dimension

\begin{tabular}{|c|c|c|c|c|}
\hline Participants & Gender & Age & Grade & Faculty \\
\hline $\mathrm{P} 1$ & Female & 19 & 2 & Faculty of Science and Literature \\
\hline $\mathrm{P} 2$ & Female & 20 & 2 & Faculty of Science and Literature \\
\hline P3 & Female & 21 & 3 & Vocational School \\
\hline P4 & Male & 19 & 2 & Faculty of Science and Literature \\
\hline P5 & Male & 20 & 2 & Faculty of Science and Literature \\
\hline P6 & Male & 19 & 3 & Faculty of Science and Literature \\
\hline P7 & Female & 20 & 2 & Faculty of Science and Literature \\
\hline P8 & Female & 20 & 3 & Faculty of Education \\
\hline P9 & Female & 22 & 4 & Faculty of Education \\
\hline $\mathrm{P} 10$ & Female & 19 & 2 & $\begin{array}{l}\text { Faculty of Economics and } \\
\text { Administrative Sciences }\end{array}$ \\
\hline P11 & Female & 18 & 1 & Faculty of Science and Literature \\
\hline $\mathrm{P} 12$ & Female & 19 & 2 & Faculty of Science and Literature \\
\hline P13 & Female & 20 & 3 & Faculty of Science and Literature \\
\hline $\mathrm{P} 14$ & Male & 22 & 4 & Faculty of Science and Literature \\
\hline
\end{tabular}

participants are second-year students and $71.5 \%$ are students of the Faculty of Arts and Sciences. It was determined that the participants in the qualitative dimension spent about 3-4 h a day on the Internet. The characteristics of the participants in the qualitative dimension and the characteristics of the sample in the quantitative dimension are similar in terms of variables. P1, P6, P7, P8, P10, P12, and P14 have scores close to the approach attitude average score $(\bar{X}=19.67 \pm 8.92)$. P2, P3, P4, P5, P9, P11, and $\mathrm{P} 13$ have scores close to the mean score of avoidance attitude $(\bar{X}=38.66 \pm 9.08)$.

\subsection{Data collection instruments}

The e-questionnaire used in the study consists of two parts; an introductory information form and an "Attitude Scale Towards E-Learning". There are 10 questions aiming to determine sociodemographic characteristics in the introductory information form. The "Attitude Scale Towards E-Learning", which is a 5-point Likert type scale developed by Haznedar and Baran (2012), consisting of 2 sub-dimensions and a total of 20 items, was used. The scale consists of approach and avoidance subdimensions. There are 10 positive statements in the approach sub-dimension, and 10 negative statements in the avoidance sub-dimension. The Cronbach $\alpha$ coefficient of the approach sub-dimension is 0.93 , and the Cronbach $\alpha$ coefficient of the avoidance sub-dimension is 0.84 (Haznedar \& Baran, 2012). In this study, the Cronbach $\alpha$ coefficient of the approach sub-dimension was calculated as 0.94 , and the Cronbach $\alpha$ coefficient of the avoidance sub-dimension was calculated as 0.91 .

Qualitative data were collected using an introductory information form and a semi-structured interview form with interview questions. Demographic information was included in the introductory information form. In the interview form, there are two open-ended questions aiming to understand the interaction experiences of 
students during the pandemic. Interview questions were first evaluated by three experts and a pilot study was conducted with three students during the preparation phase. The questions in the interview form were revised by taking expert opinions and the pilot study into consideration.

\subsection{Data collection}

In order to conduct the study in the first place, the permission of Ethics Committee was obtained. Quantitative data were collected through an online survey between April 20 and May 15, 2020. The online survey link was shared on the social media accounts of the departments or classes. An "Informed Consent Form" was presented at the beginning of the online questionnaire. Participants were asked to continue filling-in the questionnaire after giving their consent.

Interviews were held with 14 students who participated voluntarily using the online meeting tool on different days. It was stated that the interview data would not be used for any other purpose and would be kept confidential. The interviews were recorded with video or audio at intervals of several days. Each interview took an average of $35 \mathrm{~min}$.

\subsection{Data analysis}

The quantitative data were coded and evaluated using the IBM SPSS Statistics (Version 26). Descriptive statistics such as number and percentage distributions, mean and standard deviation, were used in the evaluation of descriptive information. Two independent samples t test was applied to compare the two groups in the data showing homogeneous distribution, and one-way ANOVA was applied to compare multiple groups. As a result of the one-way ANOVA test, Tukey's test was applied to determine the group that made a difference. The Mann-Whitney U test was applied to compare the two groups in the data that did not show a homogeneous distribution.

Qualitative data were analyzed according to Braun and Clarke's (2006) six-step thematic analysis process: 1) Familiarity was provided, 2) initial coding was made, 3 ) the themes were searched for potential themes, 4) the relation of the data with the themes was checked, 5) the themes were identified and named, and 6) the analysis results were reported in relation to the research question and the literature. A reliability study was conducted with an expert academician in the analysis of qualitative data and the reliability coefficient value was found to be 0.90 (Miles \& Huberman, 1994).

\section{Findings}

\subsection{Students' approach and avoidance attitudes towards distance education}

It was determined that the students' average score of approach to distance education $(\bar{X}=19.67 \pm 8.92)$ was lower than the average score of avoidance attitude 
$(\overline{X=38.66} \pm 9.08)$. The study attempted to determine whether there was a significant difference between the levels of approach and avoidance attitudes of students and various variables (Table 3 ).

It was determined that the students' mean scores for avoidance attitude differed significantly according to gender $(\mathrm{p}<0.05)$. It was determined that the mean avoidance attitude score of female students $(\bar{X}=39.02)$ was significantly higher than that of males $(\bar{X}=37.03)$ (Table 3$)$.

It was determined that the mean scores for approach and avoidance attitude differed significantly according to the success status $(\mathrm{p}<0.05)$. It was determined that students with a high level of achievement had a higher mean for the approach attitude $(\bar{X}=21.04)$, and students with a medium achievement level had a higher mean score for the avoidance attitude $(\bar{X}=39.36)$ (Table 3$)$. It was determined that the approach and avoidance attitudes of the participants differed significantly according to the monthly income level of their families $(\mathrm{p}<0.05)$. It was found that the average point of approach attitude $(\bar{X}=23.64)$ of the group with a high monthly family income level was found to be higher (Table 3).

Table 3 Approach-Avoidance Attitudes According to Students' Demographic Features

\begin{tabular}{|c|c|c|c|}
\hline \multirow[t]{2}{*}{ Variables } & \multicolumn{2}{|r|}{ Approach Attitudes } & \multirow{2}{*}{$\begin{array}{l}\text { Avoidance Attitudes } \\
\overline{\mathrm{x}} \pm \mathrm{SS}\end{array}$} \\
\hline & $\mathrm{n}$ & $\overline{\mathrm{x}} \pm \mathrm{SS}$ & \\
\hline \multicolumn{4}{|l|}{ Gender } \\
\hline Female & 562 & $19.386 \pm 8.7029$ & $39.0214 \pm 9.0895$ \\
\hline Male & 122 & $20.991 \pm 9.8379$ & $37.0328 \pm 8.9025$ \\
\hline Evaluation & & $\mathrm{Z}=-1.327, \mathrm{p}=-1.327^{*}$ & $\mathrm{t}=-2.198, \mathrm{p}=0.028^{* *}$ \\
\hline \multicolumn{4}{|l|}{ Grade average } \\
\hline Low & 78 & $18.961 \pm 10.747^{\mathrm{a}}$ & $38.282 \pm 11.300^{\mathrm{a}}$ \\
\hline Middle & 400 & $19.105 \pm 8.544^{\mathrm{a}}$ & $39.365 \pm 8.764^{\mathrm{a}}$ \\
\hline High & 206 & $21.043 \pm 8.802^{\mathrm{b}}$ & $37.456 \pm 8.652^{\mathrm{b}}$ \\
\hline Evaluation & & $\mathrm{F}=3.509, \mathrm{p}=0.030^{* * *}$ & $\mathrm{~F}=3.101, \mathrm{p}=0.046^{* * *}$ \\
\hline \multicolumn{4}{|l|}{ Income rate } \\
\hline Low & 454 & $18.991 \pm 8.807^{\mathrm{a}}$ & $39.061 \pm 9.071$ \\
\hline Middle & 146 & $19.508 \pm 8.245^{\mathrm{a}}$ & $38.678 \pm 8.818$ \\
\hline High & 84 & $23.642 \pm 9.770^{\mathrm{b}}$ & $36.511 \pm 9.390$ \\
\hline Evaluation & & $\mathrm{F}=9.901, \mathrm{p}=0.001^{* * *}$ & $\mathrm{~F}=2.809, \mathrm{p}=0.061$ \\
\hline \multicolumn{4}{|c|}{ * Man Whithney U was applied } \\
\hline \multicolumn{4}{|c|}{${ }^{* *}$ Independent Student $\mathrm{t}$ test was applied } \\
\hline \multicolumn{4}{|c|}{${ }^{* * *}$ One way ANOVA was applied } \\
\hline \multicolumn{4}{|c|}{$\begin{array}{l}\text { a,b The difference between groups with different letters in the same column is significant, the Tukey's test } \\
\text { was applied }\end{array}$} \\
\hline
\end{tabular}




\subsection{Distance education interaction experiences of students in the pandemic process}

\subsubsection{Student-student interaction}

Codings of (a) decrease in communication, (b) ending of social activities (c) ending of compulsory socialization, (d) fatigue of online relationships, (e) decreasing in pedagogical interaction out of class, and (f) online socialization opportunities were made under the theme of student-student interaction:

One participant stated that communication decreased as follows: "Our communication has decreased a lot. Everyone is dealing with their own troubles with their family. What is out of sight is also out of mind" (P4). One participant described the ending of social activities during the pandemic as follows: "After the lesson, there was going somewhere or sitting together in the canteen. Now people have become asocial at the computer. There is no activity" (P13). One participant expressed that the compulsory socialization processes were over as follows: "You know, we had to do something together with everybody even though we didn't love each other. These kinds of relationships are over now" (P7).

The exhaustion of technology-based interactions is described as follows: "People can talk on the phone to a certain extent. After a certain time, the head does not raise an eye" (P3). One participant expressed the weakening of extracurricular pedagogical interaction as follows: "There was such a situation of constantly encouraging each other during breaks, in dormitory rooms, while eating. There was a competition and sharing. These are finished" (P11).

There were also those who stated that the transition to distance education positively affected the student-student interaction and gained new dimensions. A participant described the interactions that continued smoothly in the online environment as follows: "There is no problem with my friends, we share everything through groups. We can share everything. When there is a problem, we add it to the group. They are also answering. Socializing is fine, there is no problem" (P6). A participant stated that the activities of the club of which he was a member continued online as follows: "First of all, we have a reading group. We were having meetings while we were in formal education, but there was no disconnection. Our group continues online" (P12).

\subsubsection{Student-lecturer interaction}

Codings of (a) timidity, (b) lack of sincerity, (c) decrease of participation, (d) lack of feedback, and (e) advantage were made under the theme of "student-lecturer".

In the context of student-lecturer interaction, the participants stated that they were hesitant to explain, ask questions, or discuss during the lesson: "I hesitate when asking questions. I think 'I wonder if I interrupt the broadcast?'(P9). I cannot communicate much with the teacher because I think that 'I wonder how would my voice sound?' Am I misunderstood? Will the voices of the people in the house go? I cannot communicate much with the teacher." (P3). 
Participants expressed the lack of sincerity in student-lecturer relationship as follows: "Normally, our teachers were also our guides in classical education. But in distance education, everything is calculated. So there is touch training. The atmosphere is not friendly" (P14).

During the interviews, the subject of participation in the lesson was emphasized as a factor affecting student-lecturer relations. One participant interpreted the lack of participation in the lesson as the students' not taking distance education seriously, and explained that this situation negatively affected the lecturer as follows: "Student does not attach importance to distance education. Because nobody participates. Now, it is a sad situation for the teacher in this respect. S/he opens the lesson herself/himself, s/he talks, s/he listens" (P1).

One participant explained the shortcomings of feedback as follows: "In face-toface training, there was a quicker response situation. Now I'm sending an e-mail to the teacher. Whenever s/he sees it or is available, then I get a response. Sometimes it can be too late" (P7).

Some of the participants stated that distance education was more advantageous in terms of student-lecturer interaction and it brings new dimensions to interactions. A student stated that s/he could convey her/his ideas more easily in this process:

I have learned to be able to speak a little more comfortably in this process. We were inevitably anxious when we were face to face, You know, we were anxious by thinking that 'does something wrong come out of our mouth?' Now we are more comfortable. (P6)

A participant explained that the vertical relationship between the lecturer and the student turned into a horizontal relationship as follows: "It is more of an inter-peer interaction. Normally, the teacher sits in one place, the students are opposite him/ her. But now we are doing the same as the teacher does" (P14).

\subsubsection{Student-content interaction}

Codings of (a) content with uploading notes, (b) concentration of the content, and (c) functionalization of the content were made under the theme of student-content interaction.

Most of the participants stated that they were not satisfied with the execution of only the course content in the distance education process: "I have generally listened to my live lessons, but the lessons of my lecturers who take notes are still available. There is no request for them" (P2). "One of our teachers just sent a PDF. The subject is good, but I am reading, researching and not understanding" (P10).

One participant stated that the content of the lessons in the distance education process was more intense compared to face-to-face education: "The texts can be intense in some lessons. There may be more things we do not understand" (P13). One participant explained, through the training notes, that the training load increased as follows: "They send us a note by increasing a 5-page topic that we have covered less in the lesson to 15 pages. Pages piled up notes" (P12). 
A participant explained that the lecture notes clarified the boundaries of the lesson as follows:

While some lecturers did not give notes in classical education, they started to give notes in distance education. We now know what is processed and what will be processed. Notes are very concise, understandable, useful in terms of content. I find it efficient (P10).

One participant stated that the lecture notes had become more functional and systematic as follows: "The notes given in distance education are a little more systematic. Most of the time, notes were not given in formal education. We were surprised what to do" (P8).

\subsubsection{Student-medium interaction}

In the context of the education process that moved into the home setting, the position and relationships of the student at home were evaluated under the theme of "studentmedium interaction". There are codings within this theme such as (a) leisure time increase, (b) reduction of costs, (c) technology adaptation, (d) home comfort, (e) replaying lessons at home, (f) the house decreases motivation, (g) failure to maintain self-discipline, and (h) being a female student in the pandemic.

One participant stated that conducting distance education online from home increased free time: "Distance education created a lot of time. I have as much free time as I want" (P10). One participant explained that distance education, which enables participation from home, reduced education costs as follows: "It has too many cost implications. We pay for the place where we will stay at the university. We are paying for our food. But here we are with our family. Everything is completely ready in front of us" (P8). Another aspect of distance education that is seen as advantageous is that it can be watched again at home:

When we are in a one-on-one lesson, sometimes one can become distracted while listening to the lesson. When you miss the lesson at that moment, you can't catch up with the topic. But in distance education, you can take it back and listen while at home, it has such an advantage, so it's nice. (P7)

Some of the students consider the transformation of the classroom into a virtual form and moving home as receiving education in a comfortable atmosphere:

I have the comfort of the computer, I can deal with the phone more easily. I can get up and walk around. The convenience of the computer medium is clearer. Because nobody sees or hears our voices. We communicate more easily with our family. But these don't happen in the classroom. (P1)

Another student stated that s/he kept up with technological developments in the context of attending distance education at home: "Distance education makes us feel more advanced. We are at home but we can do anything technologically" (P6). 
Some participants stated that moving the educational environment to the home reduced motivation. They stated that especially environmental stimuli specific to the home caused low motivation:

There are people sitting next to each other. Neighbors are coming, our mother says something. There is always an external factor. That's why we get very distracted. We can't focus. In other words, we feel like watching a movie in a neighborhood environment. (P9)

Another participant described the noise and negativity caused by family members as follows: "It's a big problem for those who have younger siblings. Sometimes they make noise and they want to enter the class" (P3). Some participants pointed to the extreme comfort that the home provides as another source of lack of motivation: "I don't feel much like a student, frankly, I feel a little relaxed. Because we got used to comfort at home" (P5).

If you want, you can turn down your voice and eat something on your computer, you can watch movies, you can watch TV series with your family, but you can be seen in class. The student does not listen to the lesson, either plays or eats, has breakfast early in the morning. (P11)

The inability to provide self-discipline in the home environment is explained as follows: "When I was away from home, I was able to study more disciplined and better. I was also studying in the school environment because everyone had a book or a note. I can't keep things organized at home" (P2). Another participant expressed the difficulties s/he faced in terms of self-discipline and time management as follows:

In the classroom, when we had direct interaction with the teacher, we were getting more disciplined. This is not happening at home. It is necessary to develop self-discipline and time management. I don't have these. It will be very difficult to sit down. At least for me. (P5)

Some female participants stated that education in the home environment created gender-based problems. Female students may be given more responsibilities related to household chores, and control over their mobility may increase. A female participant explained that the workload at home increased as follows:

We can have more work at home. Housework becomes prominent. For example, I have to take care of my sister when my mother goes out and goes to the market. I have to compile and collect household goods at home. (P9)

Another participant stated that she was subjected to socialization and mobility restrictions at home based on gender:

It can be a problem for us to go out or meet with people. In terms of gender, boys can be treated more flexibly and girls can be treated more strictly on these issues. So this can be challenging for us to socialize. Disputes can occur at home 'Why do you go out, why do you keep coming late?'. (P13) 


\section{Discussion}

In the quantitative dimension, it was determined that students' avoidance attitudes towards distance education were stronger than their approach attitudes. This result coincides with the results obtained from other studies conducted during the pandemic (Coman et al., 2020). In this study, it was determined that female students' avoidance attitudes towards distance education were stronger than those of male students. Similar results were obtained in another study (Atasoy et al., 2020). Female students' perceptions of threat and their sensitivity to loss of control can be intense, and they can become more vulnerable in times of crisis or trauma (Padrón et al., 2021). In this study, it was determined that students with higher family income levels had stronger approach attitudes to distance education. The factors of having digital resources, the ability to use resources, and the quality of the resources can be related to the socioeconomic background (Lee, 2008). Financial opportunities can strengthen the capacity and willingness to use digital resources.

The qualitative findings of the study support the quantitative findings. Students mostly mentioned various difficulties while describing their distance education experiences. The decrease in communication, the elimination of compulsory socialization, and the end of social activities were frequently emphasized. In other studies, it is stated that one of the biggest disadvantages of distance education during the pandemic is the lack of social interaction (Aguilera-Hermida, 2020; Dutta \& Smita, 2020). The transformation of the interaction can negatively affect learning. However, online platforms, clubs and extra-curricular activities can bring new dimensions to interactions. In this study, a small number of participants stated that distance education brought new dimensions to socialization and interactions during the pandemic. In the interviews, it was stated that the extra-curricular pedagogical interaction between students was weakened. This result coincides with the results in the literature (Dutta \& Smita, 2020; Irembere \& Lubani, 2020). The finding regarding fatigue with technology-based communication obtained in this study is similar to the results of other studies that indicate the exhausting nature of distance education during the pandemic (Aguilera-Hermida, 2020) and its negative effects on health (Aduba \& Mayowa-Adebara, 2020).

In the interviews, it was frequently emphasized that the student-lecturer interaction changed. During the lesson, the students stated that they had difficulties and hesitated about explaining their opinions and asking questions of the lecturers. The decrease in sincerity in relations with the lecturers and problems in feedback are other difficulties. These results are parallels to the results of anxiety about appearening foolish online, refraining from making presentations or expressing opinions (Coman et al., 2020), refraining from asking questions and explaining (Saleh et al., 2021), lack of sincerity (Chattaraj \& Vijayaraghavan, 2021), and missing feedback (Irembere \& Lubani, 2020).

Negative reaction to the delivery of the lessons by only transferring the lecture notes to the system is remarkable. It was emphasized that the lessons conducted in this way negatively affected the students' learning and weakened their motivation. 
Some stated that the content of the lesson and the notes were more intense compared to face-to-face education. There are other studies indicating that the content became denser and more challenging during the pandemic (Aduba \& MayowaAdebara, 2020), and the educational burden increased (Coman et al., 2020). In this study, there were also students who stated that the content and lecture notes made the boundaries of the lessons clear, and in this respect distance education was more systematic and functional.

In the interviews, the advantages of reducing education costs, increasing leisure time, home comfort, and being able to repeatedly watch lessons at home were mentioned in the context of the environment. These results coincide with the results of reduction of costs in the literature (Saleh et al., 2021), increased leisure time (Yates et al., 2020), home comfort (Fatonia et al., 2020), and ease of watching lessons at home (Mishra et al., 2020). The disadvantages of distance education at home were described in the interviews, such as decreased motivation, inability to develop selfdiscipline, inability to use time effectively, noise, and excessive non-educational stimuli. These results coincide with the results of reduced concentration at home in the literature (Aguilera-Hermida, 2020), inability to place a boundary between home life and education life (Yates et al., 2020), insufficient learning space at home (Coman et al., 2020), noise and other adverse environmental conditions (AguileraHermida, 2020; Coman et al., 2020).

Some female participants in the study stated that the home could produce genderbased negativity. Female students may encounter problems with being directed to housework such as childcare or cleaning, or restricting socialization. Another study indicates that during the pandemic, the housework or care burden of female students in the context of traditional gender roles increased (Padrón et al., 2021).

\section{Conclusion}

As a result, it was revealed that during the pandemic, students had strong avoidance attitudes towards distance education and mostly described their negative experiences. It was revealed that the students' interactions with each other and with the lecturers were weakened during this process. It was concluded that course contents, materials and notes functionalized the lessons on the one hand, and increased the workload of the students by their concentration on the other. The transfer of education to the home environment through digital technologies during the pandemic has been the source of both various opportunities and various risks in the context of educational interactions. It is not possible to consider these results separately from the general context shaped by the crisis created by the pandemic. In this respect, it is not possible to generalize the results reached to the distance education normally carried out. It should be kept in mind that each participant whose views are consulted is both a member of the society in the grip of the pandemic, and a student who had continued his/her education within the established patterns of face-to-face education until the pandemic began. 


\section{Declarations}

Conflict of interest No potential conflict of interest was declared by the author.

\section{References}

Aduba, D. E., \& Mayowa-Adebara, O. (2020). Online platforms used for teaching and learning during the COVID-19 era: The case of lis students in Delta State University Abraka. International Information \& Library Review, 1-36. https://doi.org/10.1080/10572317.2020.1869903

Aguilera-Hermida, A. P. (2020). College students' use and acceptance of emergency online learning due to Covid-19. International Journal of Educational Research Open, 1, 100011. https://doi.org/10. 1016/j.ijedro.2020.100011

Atasoy, R., Özden, C., \& Kara, D. N. (2020). Covid-19 pandemi sürecinde yapılan E-ders uygulamalarının etkililiğinin öğrencilerin perspektifinden değerlendirilmesi. Electronic Turkish Studies, 15(6), 95-122. https://doi.org/10.7827/TurkishStudies.44491

Bozkurt, A., \& Sharma, R. C. (2020). Emergency remote teaching in a time of global crisis due to CoronaVirus pandemic. Asian Journal of Distance Education, 15(1), i-vi. https://doi.org/10.5281/ zenodo.3778083

Bernard, R. M., Abrami, P. C., Borokhovski, E., Wade, C. A., Tamim, R. M., Surkes, M. A., \& Bethel, E. C. (2009). A Meta-analysis of three types of interaction treatments in distance education. Review of Educational Research, 79(3), 1243-1289. https://doi.org/10.3102/0034654309333844

Braun, V., \& Clarke, V. (2006). Using thematic analysis in psychology. Qualitative Research in Psychology, 3(2), 77-101. https://doi.org/10.1191/1478088706qp063oa

Chattaraj, D., \& Vijayaraghavan, A. P. (2021). Why learning space matters: A script approach to the phenomena of learning in the emergency remote learning scenario. Journal of Computers in Education, 1-22. https://doi.org/10.1007/s40692-021-00182-z.

Chen, T., Peng, L., Jing, B., Wu, C., Yang, J., \& Cong, G. (2020). The impact of the COVID-19 pandemic on user experience with online education platforms in China. Sustainability, 12(18), 7329. https:// doi.org/10.3390/su12187329

Coman, C., Țîru, L. G., Meseșan-Schmitz, L., Stanciu, C., \& Bularca, M. C. (2020). Online teaching and learning in higher education during the Coronavirus pandemic: Students' perspective. Sustainability, 12(24), 10367. https://doi.org/10.3390/su122410367

Creswell, J. W. (2014). Research design: Qualitative, quantitative and mixed methods approaches (4th ed.). Sage.

Creswell, J. W. (2015). A concise introduction to mixed methods research. Sage.

Creswell, J. W. \& Plano-Clark, V. L. (2015). Karma yöntem araştırmalarının tasarımı ve yürütülmesi (Y. Dede \& S. B. Demir). Anı (2011).

Dutta, S., \& Smita, M. K. (2020). The impact of COVID-19 pandemic on tertiary education in Bangladesh: Students' perspectives. Open Journal of Social Sciences, 8(09), 53-68. https://doi.org/10. 4236/jss.2020.89004

Fatonia, N.A., Nurkhayatic, E., Nurdiawatid, E., Pamungkasf, F.G., Adhag, S., Purwantoi, I.A., Julyantoj, O., \& Azizik E. (2020). University students online learning system during Covid-19 pandemic: Advantages, constraints and solutions. Systematic reviews in pharmacy, 11(7), 570-576. https://doi. org/10.31838/srp.2020.7.81.

Han, H., \& Johnson, S. D. (2012). Relationship between students' emotional intelligence, social bond, and interactions in online learning. Journal of Educational Technology \& Society, 15(1), 78-89.

Haznedar, Ö., \& Baran, B. (2012). Eğitim fakültesi öğrencileri için e-öğrenmeye yönelik genel bir tutum ölçeği geliştirme çalışması. Eğitim Teknolojisi Kuram ve Uygulama, 2(2), 42-59. https://doi.org/10. 17943/etku.84225

Hodges, C., Moore, S., Lockee, B., Trust, T., \& Bond, A. (2020). The difference between emergency remote teaching and online learning. Educause Review, 27, 1-12 https://er.educause.edu/articles/ 2020/3/thedifference-between-emergency-remote-teaching-and-online-learning

International Labour Organization. (2020). ILO Sectoral Brief: COVID-19 and the Education Sector. March, 1-8. https://www.ilo.org/wcmsp5/groups/public/---ed_dialogue/---sector/documents/brief ingnote/wcms_742025.pdf 
Irembere, W. R., \& Lubani, R. M. (2020). Transitioning to emergency remote learning amidst Covid19 and its effects on higher education students: A case study. International Forum Journal, 23(2), 178-202 https://journals.aiias.edu/info/article/view/321

Karadağ, E., \& Yücel, C. (2020). Yeni tip Koronavirüs pandemisi döneminde üniversitelerde uzaktan eğitim: Lisans öğrencileri kapsamında bir değerlendirme çalışması. Yükseköğretim Dergisi, 10(2), 181-192. https://doi.org/10.2399/yod.20.730688

Lee, L. (2008). The impact of young People's internet use on class boundaries and life trajectories. SAGE, 42(1), 137-153. https://doi.org/10.1177/0038038507084829

Liaw, S. S., Huang, H. M., \& Chen, G. D. (2007). Surveying instructor and learner attitudes toward e-learning. Computers \& Education, 49(4), 1066-1080. https://doi.org/10.1016/j.compedu.2006.01. 001

Miles, M. B., \& Huberman, A. M. (1994). Qualitative data analysis: An expanded sourcebook. Sage Publications.

Mishra, L., Gupta, T., \& Shree, A. (2020). Online teaching-learning in higher education during lockdown period of COVID-19 pandemic. International Journal of Educational Research Open, 1, 100012. https://doi.org/10.1016/j.ijedro.2020.100012

Morse, J. M. (1991). Approaches to qualitative-quantitative methodological triangulation. Nursing Research, 40, 120-123. https://doi.org/10.1097/00006199-199103000-00014

Padrón, I., Fraga, I., Vieitez, L., Montes, C., \& Romero, E. (2021). A study on the psychological wound of COVID-19 in university students. Frontiers in Psychology, 12, 9. https://doi.org/10.3389/fpsyg. 2021.589927

Purarjomandlangrudi, A., \& Chen, D. (2020). Exploring the influence of learners' personal traits and perceived course characteristics on online interaction and engagement. Educational Technology Research and Development, 68(5), 2635-2657. https://doi.org/10.1007/s11423-020-09792-3

Saleh, M. N. I., Sarı, R., \& Alim, P. (2021). University students' perception on the implementation of online learning during the Covid-19. Nazhruna: Jurnal Pendidikan Islam, 4(1), 1-17. https://doi. org/10.31538/nzh.v4i1.1022

Teddlie, C., \& Tashakkori, A. (2009). Foundations of mixed methods research: Integrating quantitative and qualitative approaches in the social and behavioral sciences. Sage.

United Nations Educational, Scientific and Cultural Organization (UNESCO). (2020). Startling digital divides in distance learning emerge. https://en.unesco.org/news/startling-digital-divides-distancelearning-emerge

Van Den Berg, G. (2020). Context matters: Student experiences of interaction in open distance learning. Turkish online journal of. Distance Education, 21(4), 223-236. https://doi.org/10.17718/TOJDE. 803411

Vlachopoulos, D. (2020). COVID-19: Threat or opportunity for online education?. Higher learning research Communications, 10(1), 2. https://doi.org/10.18870/hlrc.v10i1.1179.

Yates, A., Starkey, L., Egerton, B., \& Flueggen, F. (2020). High school students' experience of online learning during Covid-19: The influence of technology and pedagogy. Technology, Pedagogy and Education. https://doi.org/10.1080/1475939X.2020.1854337

Zhang, Q., \& Yu, Z. (2021). A literature review on the influence of Kahoot! On learning outcomes, interaction, and collaboration. Education and Information Technologies, 1-29. https://doi.org/10.1007/ S10639-021-10459-6

Publisher's note Springer Nature remains neutral with regard to jurisdictional claims in published maps and institutional affiliations. 